\title{
EXHIBITORS AND SPONSORS
}

\section{Annual Conference Exhibitors and Sponsors}

\section{Exhibitors}

ACLS Humanities E-Books

Alexander Street Press

Anabaptist Mennonite Biblical Seminary

Association of Christian Librarians

Association of Religion Data Archives (ARDA)

ATLA Endowment Committee

ATLA Press

ATLA Products and Services

Baylor University Press

Bloomsbury Publishing

BRILL Academic Publishers, Inc.

Chalice Press

Claremont Press

Concordia Theological Seminary

David C. Lachman, PhD

DE GRUYTER

Digital Theological Library

Digitalia Hispanica

Discipleship Resources International (DRI)

Duke University Press

EBSCO

Equinox Publishing LTD

Fortress Press 
Gorgias Press

Hendrickson Publishers \& Rose Publishing

Institute of Mennonite Studies

InterVarsity Press

ISD, Distributor of Scholarly Books

JSTOR

Langham Partnership

Midwest Library Service

Mohr Siebeck

OCLC

Orbis Books

Oxford University Press

PALNI

Peeters Publishers

Penn State University Press

Project MUSE

re:loom

Saint Meinrad School of Theology

SCELC

The Crowley Company

The Wabash Center for Teaching and Learning in Theology and Religion Theological Book Network

V\&R Academic

Westminster John Knox Press

Windows Booksellers/Wipf and Stock Publishers 


\section{Sponsors}

Major Sponsor

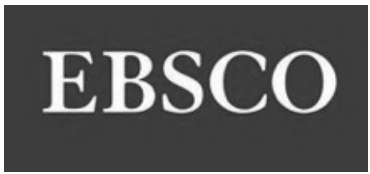

EBSCO Publishing

Contributing Sponsor

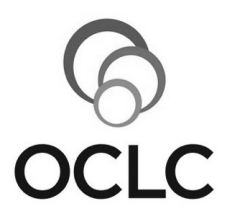

OCLC

Supporter

\section{粕 $\mathrm{AMBS}$}

Anabaptist Mennonite Biblical Seminary

Anabaptist Mennonite Biblical Seminary
Sponsor

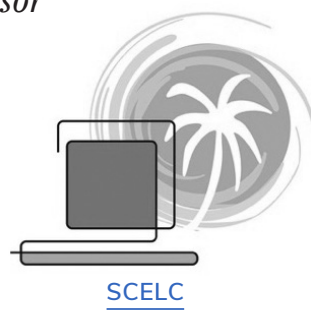

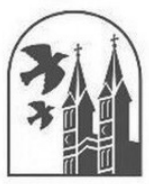

\section{Saint Meínrad}

Saint Meinrad School of Theology

CBIZ

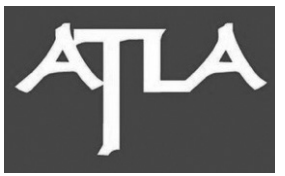

ATLA Products and Services
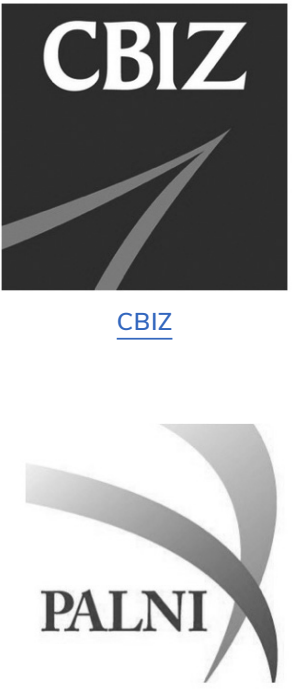

PALNI 